\title{
Does Agricultural Export Promote Nepalese Economic Growth? ARDL Approach Using Structural Break
}

\author{
Amogh Ghimire ${ }^{1,2}$, Fu Weiwei ${ }^{1,2}$ and Peifen Zhuang ${ }^{1,2}$ * \\ ${ }^{1}$ College of Economics and Management, Fujian Agriculture and Forestry University, Fuzhou 350002, China \\ ${ }^{2}$ Research Center for the South Pacific Island Countries, Fujian Agriculture and Forestry University, Fuzhou 350002, China
}

\begin{abstract}
This study examines the impact of agricultural export on the economic growth in Nepal for the time period of 1970-2015. In this analysis, researchers used the ARDL model using structural break to investigate the relationship between agricultural exports and economic growth in Nepal. Agricultural land, exchange rate, foreign direct investment, trade openness and agricultural environmental pollution have all been included in this analysis. According to estimates, ARDL, tend towards short-run relationship has been validated. Whereas, in the long-run relation we found negative relation. Furthermore, this study found that agricultural land is directly affecting economic growth. This study recommends policies that improve agricultural production and trade should be strongly pursued to help boost a country's economic growth
\end{abstract}

\section{Introduction}

Agriculture plays an essential role in promoting socialeconomic development in several nations. It is the primary source of employment, livelihood, and food security, and there are no feasible alternatives to agriculture in numerous developing countries. According to the FAO 2019 report, "it was projected that almost $8.9 \%$ of the total population or 690 million people are undernourished" [1]. Global food demand is expected to double in the next 50 years as the natural resources that sustain agriculture grow scarce, strained, and susceptible to climate change. Agriculture accounts for at least $40 \%$ of gross domestic product (GDP) and $80 \%$ of jobs in different developing countries. Simultaneously, more than $70 \%$ of the world's population lives in rural areas, where the majority rely on subsistence farming [2]. The success of this continuity remains primarily based on the direct impact it has on the national economy and the stimulation by the agricultural sector to the growth of other sectors of the economy. Agriculture has substantial effects on the rest of the economy due to economic growth[3-5]. Agriculture directly affects macroeconomic policies, prices, and exchange rates [6,7]. Therefore, the role of agriculture and its relations with the rest of the economy must be understood. When focused on small farms and the goods they produce, agricultural development has proved highly pro-poor.

Nepal is a nation that is culturally based on agriculture. Agriculture accounts for one-third of GDP, and there are numerous agricultural prospects, owing to the country's diverse agro-climate [8]. To satisfy the demands of the enormous market in neighbouring India and China, specific niche goods with a competitive edge could be produced in a fair quantity as the buying power of the inhabitants of those countries grew. As suggested by the Government of Nepal (GON) a few years earlier, the products that could be exported to other countries to offset trade imbalances, improve export promotion and reduce imports, and promote Nepal's move from the least developed countries (LDC) to the Developing countries on time[9]. Compared to other countries in South Asia, Nepal performs well on specific metrics, such as the degree of the undernourished population, while Nepal is the lowest on other indicators, such as infant stunting. More precisely, throughout Nepal's regions, the benefits from liberalization were uneven [10,11]. Nepal has had a long history of trade deficits. Nepal's trade deficit has been increasing for decades. Nepal has had a long history of trade deficits. Nepal's trade deficit has been rising for decades [4]. Despite the decreasing amount of trade, herbs' value is still growing [12]. In terms of policy priorities, ginger has acquired good coverage. The export trend is always fluctuating, but ginger export to India's western area is more steady than the eastern region of Nepal [13].

Agricultural exports has had a significant impact on the economy and rural sector to led economic prosperity in the future [14]. The agricultural export is of tremendous importance to the economy, but surprisingly, studies on the empirical relationship between agricultural exports and economic growth have been relatively overlooked in the literature, considering the awareness of its position in the development process [15]. Our study concentrates on the relationship between agricultural exports and economic growth for Nepal.

\footnotetext{
* Corresponding author: peifenzhuang@fafu.edu.cn
} 


\section{Method and Methodology}

In this study, the relationship between exports and economic growth is explained by a model guided by the work of Blecker (2009) [16], Toyin 2016 (2016) [17], and Abosedra and Tang (2019) [18]. The model is updated to contain only the variables of concern in this study and can be represented as follows Equation 1.

$$
\begin{gathered}
R G D P_{t}=\alpha_{0}+\alpha_{1} A E X_{t}+\alpha_{2} A G l_{t}+\alpha_{3} F D I_{t}+\alpha_{4} E X R_{t} \\
+\alpha_{5} T_{R} O_{t}+\alpha_{6} A E P_{t}+\varepsilon_{t}
\end{gathered}
$$

This research examines multiple aspects of determinant factors that affect the economic growth of South Asian countries. The study used annual data for over 45 years (1970 to 2015) from World Bank, FAO, and OurWorldindata. A clear referenced econometric framework was used to carry out the fundamental analysis. The association among the variables was empirically examined with the help of the following econometric models. The variable including economic growth $(R G D P)$ GDP per capita growth (Annual \%), agricultural export $(A E X)$ refers to agricultural Raw Materials exports (\% of merchandise exports)., agricultural land $(A G L)$ (\% of land area), the exchange rate $(E X R)$ (local Currency unit (LCU) relative to the USD), foreign direct investment $(F D I)$ to net inflows (\% of GDP), trade openness(TRO) is calculated as the sum of a country's exports and imports as a share of that country's GDP ( $\%$ )and for the agricultural environmental pollution $(A E P)$ total GHG emissions measured in gigagrams.

Since it is a long time, we used the structural break unit root test to decide whether the sequence is stationary except in the face of a potential structural break by Enders and Lee (2012) [19]. In comparison to other cointegration testing forms, $A R D L$ Bound can be used regardless of whether the analysis variables are $I(0)$ or $I(1)$ or both. However, the list must not be $I(2)$, or we cannot use the $A R D L$ Bound Test. The unit root test were augmented Dickey-Fuller test (ADF), and Phillip Person of the degree series, and the first distinctions are implemented as in Equation 2.

$$
\Delta Y_{t}=\alpha+\beta Y_{t-1}+\sum_{j=1}^{p} \delta_{j} \Delta Y_{t-j}+\varepsilon_{t}
$$

This is achieved by checking stationary variables to guarantee that none of the variables is $I(2)$. In the second question, the ARDL Model is built based on the Akaike knowledge Criterion $(A I C)$. In the case of a structural break, we would use the ARDL Bound Test method to cointegrate to determine the long-term co-integration of the series. However, the series must not be $I(2)$, or the ARDL Bound Test may not be utilized as in Equation 3.

$$
\begin{aligned}
\Delta \mathrm{RGDP}_{t}=\alpha_{0}+ & \sum_{i=1}^{n} \beta_{1} \Delta R G D P_{t-\mathrm{i}} \sum_{i=1}^{n} \beta_{2} \Delta A E X_{t-\mathrm{i}} \\
& +\sum_{i=1}^{n} \beta_{3} \Delta A G L_{t-\mathrm{i}}+\sum_{i=1}^{n} \beta_{4} \Delta F D I_{t-\mathrm{i}} \\
& +\sum_{i=1}^{n} \beta_{5} \Delta E X R_{t-\mathrm{i}}+\sum_{i=1}^{n} \beta_{6} \Delta T R O_{t-\mathrm{i}} \\
& +\sum_{i=1}^{n} \beta_{7} \Delta A E P_{t-\mathrm{i}}+\alpha_{1} \Delta \mathrm{RGDP}_{t-1} \\
& +\alpha_{2} \Delta A E X_{t-1}+\alpha_{3} \Delta A G L_{t-1} \\
& +\alpha_{4} \Delta F D I_{t-1}+\alpha_{5} \Delta E X R_{t-1} \\
& +\alpha_{6} \Delta T R O_{t-1}+\alpha_{7} \Delta A E P_{t-1} \\
& +\alpha_{8} D u m m y_{t}+\varepsilon_{t}
\end{aligned}
$$

The null hypothesis in all above equations is as follows:

$$
\alpha_{1}=\alpha_{2}=\alpha_{3}=\alpha_{4}=\alpha_{5}=\alpha_{6}=\alpha_{7}
$$

The null hypothesis in the above equations is that there is no long-term reexamination. In the equation, a relationship exists between the variables. The Wald F-test is used for this purpose. It senses the general meaning of the variables' lagged values in the equation and provides the critical F-statistic and upper and lower values. When the F figures are over the upper critical point, and vice versa, the proof of co-integration is found. The conclusion is inconclusive in situations where F-statistics are between the upper and lower bound values. Cointegrating equations are estimated using a long-term error, referred to as the error correction term in the error correction model after co-integration between variables is established. It illustrates the speed of transition in longterm factors, which provides an understanding of the partnership's longevity.

\section{Result and Discussion}

In Table 1, The economic growth (RGDP) has also shown a significant variation of positive and negative. For Nepal, the maximum value is 7.17 , while the minimum value is 5.21 .

Table 1. Descriptive statistics

\begin{tabular}{cccccccccc}
\hline & Mean Med Max & Mini & $\begin{array}{c}\text { Std. Skewness } \\
\text { Dev. }\end{array}$ & $\begin{array}{c}\text { Kurtosis Jarque- } \\
\text { Bera }\end{array}$ \\
\hline$R G D P$ & 2.12 & 2.21 & 7.17 & -5.21 & 2.64 & -0.78 & 3.71 & 5.60 \\
$A E X$ & 12.42 & 3.11 & 48.02 & 0.45 & 16.72 & 1.10 & 2.41 & 7.09 \\
$A G L$ & 28.74 & 28.89 & 29.71 & 25.89 & 0.83 & -1.99 & 7.30 & 65.76 \\
$E X R$ & 44.72 & 45.66 & 102.41 & 10.13 & 29.94 & 0.20 & 1.56 & 4.32 \\
$F D I$ & 0.12 & 0.03 & 0.55 & -0.10 & 0.18 & 1.15 & 2.90 & 9.79 \\
$T R O$ & 39.50 & 42.74 & 66.53 & 13.21 & 13.70 & -0.15 & 2.31 & 1.08 \\
$A E P$ & 18.71 & 18.11 & 24.77 & 12.74 & 3.36 & 0.09 & 2.14 & 1.48 \\
\hline
\end{tabular}


In table 2, The lag selection process results are reported in Tables 2. As seen, all lag selection criteria $L R, F P E, A I C, S C$ and $H Q$ ) select lag length 1 for Nepal.

Table 2. VAR Lag Order Selection

\begin{tabular}{ccccccc}
\hline \multicolumn{7}{c}{ VAR Lag Order } \\
\hline Lag & LogL & LR & FPE & AIC & SC & HQ \\
& -399.27 & NA & 9453.71 & 29.02 & 29.35 & 29.12 \\
1 & -185.82 & $304.92 *$ & $0.08^{*}$ & $17.27 *$ & $19.93 *$ & $18.08^{*}$ \\
\hline
\end{tabular}

In Table 3, the ADF unit root test provides a dummy for structure break for mean changes during each structure break and pattern transition. The $A D F$ Unit with Interception and trend are recorded and indicate that all variables are non-stationary at the level, whereas all variables were stationary at the $1 \%$ significance level at the first difference.

Table 3. Unit Root Tests

\begin{tabular}{|c|c|c|c|c|c|c|}
\hline & \multicolumn{6}{|c|}{ ADF Test } \\
\hline & \multicolumn{2}{|c|}{$\begin{array}{c}\text { With } \\
\text { Constant }\end{array}$} & \multicolumn{2}{|c|}{$\begin{array}{c}\text { With } \\
\text { Constant \& } \\
\text { Trend } \\
\end{array}$} & \multicolumn{2}{|c|}{ Structure Break } \\
\hline & Level & $\Delta$ & Level & $\Delta$ & $\begin{array}{c}\text { Break } \\
\text { year }\end{array}$ & Significance \\
\hline$R G D P$ & $\begin{array}{l}-2.10 \\
(0.24)\end{array}$ & $\begin{array}{c}-9.48 \\
(0.00) \\
* * *\end{array}$ & $\begin{array}{c}-7.36 \\
(0.00) \\
* * *\end{array}$ & $\begin{array}{l}-9.37 \\
(0.00) \\
* * *\end{array}$ & 1983 & $\begin{array}{l}-9.91 \\
(0.01) \\
* * *\end{array}$ \\
\hline$A E X$ & $\begin{array}{l}-0.26 \\
(0.91)\end{array}$ & $\begin{array}{c}-2.01 \\
(0.28)\end{array}$ & $\begin{array}{l}-1.42 \\
(0.82)\end{array}$ & $\begin{array}{l}-8.81 \\
(0.00) \\
* * *\end{array}$ & 2000 & $\begin{array}{c}-19.06 \\
(0.01) \\
* * *\end{array}$ \\
\hline$A G L$ & $\begin{array}{c}-2.87 \\
(0.05) \\
*\end{array}$ & $\begin{array}{c}-6.63 \\
(0.00) \\
* * *\end{array}$ & $\begin{array}{l}-2.05 \\
(0.55)\end{array}$ & $\begin{array}{l}-4.18 \\
(0.00) \\
* * *\end{array}$ & 2005 & $\begin{array}{c}-7.98 \\
(0.01) \\
* * *\end{array}$ \\
\hline$E X R$ & $\begin{array}{c}1.32 \\
(0.99)\end{array}$ & $\begin{array}{c}-4.83 \\
(0.00) \\
* * *\end{array}$ & $\begin{array}{l}-2.71 \\
(0.23)\end{array}$ & $\begin{array}{l}-5.06 \\
(0.00) \\
* * *\end{array}$ & 2007 & $\begin{array}{l}-5.73 \\
(0.01) \\
* * *\end{array}$ \\
\hline FDI & $\begin{array}{c}-2.89 \\
(0.05) \\
*\end{array}$ & $\begin{array}{c}-8.30 \\
(0.00) \\
* * *\end{array}$ & $\begin{array}{c}-3.97 \\
(0.01) \\
* *\end{array}$ & $\begin{array}{l}-8.20 \\
(0.00) \\
* * *\end{array}$ & 2007 & $\begin{array}{c}-5.08 \\
(0.01) \\
* * *\end{array}$ \\
\hline TRO & $\begin{array}{l}-1.69 \\
(0.42)\end{array}$ & $\begin{array}{c}-5.33 \\
(0.00) \\
* * *\end{array}$ & $\begin{array}{l}-1.50 \\
(0.81)\end{array}$ & $\begin{array}{c}-5.36 \\
(0.00) \\
* * *\end{array}$ & 1994 & $\begin{array}{c}-6.23 \\
(0.01) \\
* * *\end{array}$ \\
\hline$A E P$ & $\begin{array}{l}-0.27 \\
(0.91)\end{array}$ & $\begin{array}{c}-5.89 \\
(0.00) \\
* * *\end{array}$ & $\begin{array}{l}-1.91 \\
(0.62)\end{array}$ & $\begin{array}{l}-5.81 \\
(0.00) \\
* * *\end{array}$ & 1992 & $\begin{array}{l}-6.68 \\
(0.01) \\
* * *\end{array}$ \\
\hline
\end{tabular}

Note: $\Delta$ represents the first differences, $* * *, * *$, and $*$ indicate statistical significance at $1 \%, 5 \%$, and $10 \%$ levels, respectively. *MacKinnon (1996) one-sided p-values [20].*Vogelsang (1997) [21] and Narayan and Smyth (2005) asymptotic one-sided pvalues for $\mathrm{ADF}$ test for the structural break [22].

In Table 4, F statistic was between lower and upper limit essential values for all countries. ARDL residuals were normally distributed and are thus exempt from the issue of serial correlation (lag was used if any correlation was found) and heteroskedasticity (Hetro) use of ARDL White's Test done for heteroskedasticity found in data [23]. Agricultural land and agricultural export were significant factors of economic growth (RGDP) in Nepal. At $10 \%$ and $5 \%$ level of significance, the effect of agricultural land and agricultural export (AEX) on economic growth was negative, respectively. The coefficient (-4.44) of agricultural land and (-0.09) of agricultural export indicates that $1 \%$ increase in agricultural land and agricultural export deteriorates the economic growth by 4.44 and $0.09 \%$ in the long-run, respectively. Rashid (2012) [24] found a similar result, found that real Nepalese exports have a negative and insignificant effect on economic growth. Syed et al. (2015)[25] illustrates that agricultural exports negatively affect the economic growth.

The ECT $(-1.43)$ was significant at $1 \%$ level for economic growth. An immensely significant negative sign of the ECT strengthens the long-run relationship among the variables. The speed of adjustment from the previous year's disequilibrium in economic growth to the current year's equilibrium was $143 \%$. At the $1 \%$ level for agricultural export, the ECT (-0.15) was significant.

Table 4. Estimated Long Run Coefficients

\begin{tabular}{|c|c|c|}
\hline & Long-Run & Short-Run \\
\hline AEX & $-0.09(-2.15)^{* *}$ & $-0.2(-3.52)^{* * *}$ \\
\hline AGL & $-4.44(-1.86)^{*}$ & \\
\hline FDI & $0.44(0.14)$ & \\
\hline EXR & $-0.03(-0.49)$ & \\
\hline TRO & $0.10(1.04)$ & $-1.91(-2.43)^{* *}$ \\
\hline AEP & $0.42(0.81)$ & \\
\hline C & $122.58(1.83)^{*}$ & \\
\hline CointEq (-1) & & $-1.43(-11.88)^{* * *}$ \\
\hline Dummy & $-9.13(-3.94)^{* * *}$ & $-9.13(-4.90) * * *$ \\
\hline Lag length & $(1,1,0,0,1,0,0)$ \\
\hline Fstats (overall) & \multicolumn{2}{|c|}{$5.41 * * *$} \\
\hline Bounds Test (at 1\%) & F-stat & \multicolumn{2}{|c|}{12.69} \\
\cline { 2 - 4 } & LB & 2.88 \\
\cline { 2 - 4 } & UB & \multicolumn{2}{|c|}{3.99} \\
\hline Diagnostics & JB & \multicolumn{2}{|c|}{6.58} \\
\cline { 2 - 4 } & LM & \multicolumn{2}{|c|}{0.03} \\
\cline { 2 - 4 } & Hetro & \multicolumn{2}{|c|}{0.14} \\
\hline
\end{tabular}

Note: $* * *, * *$ and $*$ indicate statistical significance at $1 \%, 5 \%$ and $10 \%$ level respectively.

In Fig 1, it can be concluded based on the plots that the approximate ARDL equations are stable as the CUSUM lines do not cross the boundaries at the statistical significance level of $5 \%$. Whereas, in Fig 2 CUSUMQ cross the boundaries line. The null hypothesis notes that the ECM coefficients were constant and should not be discarded if the plots lie beyond the $5 \%$ significance level range.

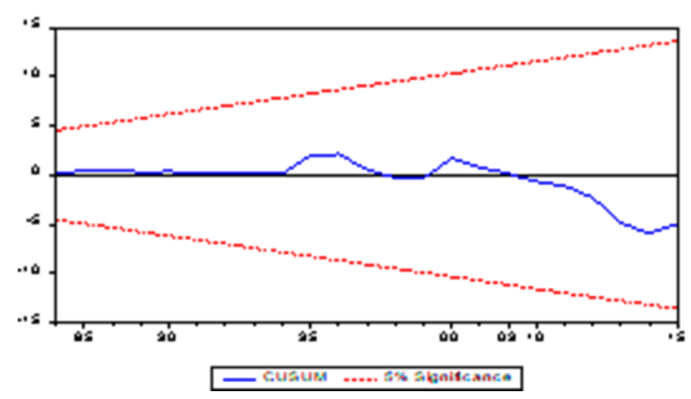

Fig. 1. CUSUM Test 


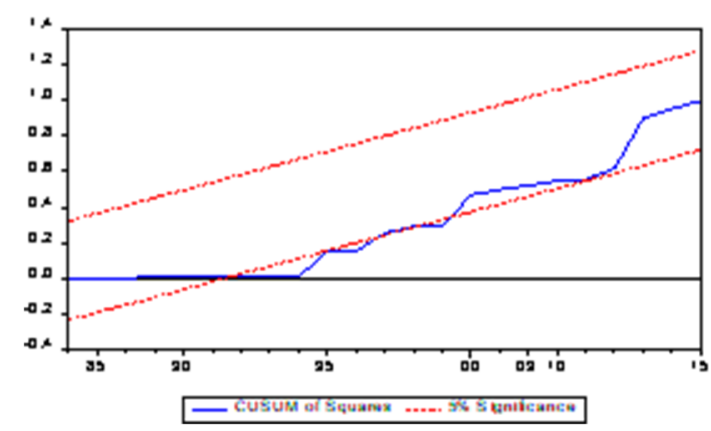

Fig. 2. CUSUMQ Test

\section{Conclusions and Recommendations}

The purpose of this study is to examine the impacts of agricultural export on Nepal's economic growth using the Structure Beak unit root test, ARDL for the period from 1970 to 2015. Agricultural export has a positive and significant role in Nepal's economic growth in the short run. This research provides further empirical evidence to identify that Nepalese agricultural export does not contribute to the economic growth in the long run. Agricultural land tends to be deregulated for greater profitability. As the study finds that Nepal's agricultural exports have been negatively related to GDP growth in the long run, it is necessary to adjust the framework and pattern of foreign trade in Nepal. It is also worth mentioning that Nepal can introduce structural changes to agricultural exports by converting its agricultural exports into value-added products. Additionally, our study suffers from several limitations - notably related to period and variables such as labour, interest rate, and remittance. With this limited study, it is unknown whether they also have a determinant economic growth factor. In future, this study was restricted to annual data but could be expanded to month or quarter further research.

\section{References}

1 FAO I UNICEF, WFP and WHO. The State of Food Security and Nutrition in the World 2020. Transforming food systems for affordable healthy diets.

2 Mondiale B. World Bank Report (2008) Agriculture for Development. 2008.

3 Ableeva A, Salimova G, Gusmanov R, Lubova T, Efimov O, Farrahetdinova A. The role of agriculture in the formation of macroeconomic indicators of national economy. Montenegrin Journal of Economics 2019; 15: 183-193.

4 Phiri J, Malec K, Majune SK, Appiah-Kubi SNK, Maitah M, Maitah K, Gebeltová Z, Abdullahi KT. Agriculture as a determinant of Zambian economic sustainability. Sustainability (Switzerland) 2020; 12.

5 Balakrishna G, Moparthi NR. Study report on Indian agriculture with IoT. International Journal of Electrical and Computer Engineering 2019; 10: 2322-2328.
6 Mehrara M, Baghbanpour J. The Contribution of Industry and Agriculture Exports to Economic Growth: The Case of Developing Countries. World Scientific News 2016; 46.

7 Reis N. A farewell to urban/rural bias: peripheral finance capitalism in Mexico. Journal of Peasant Studies 2019; 46: 702-728.

8 Ghimire A, Zhuang P, Shrestha A, Awan SA, Nicole NA, Toai DB. Situational Analysis of Belt and Road Initiative in Nepal. 2018; 184: 679-683.

9 Paudel MN. Prospects and limitations of agriculture industrialization in Nepal. Agronomy Journal of Nepal 2016; 4: 38-63.

10 Shrestha PK. Journal of Development Innovations. 2017; 1: 60-83.

11 Pyakuryal B, Roy D, Thapa YB. Trade liberalization and food security in Nepal. Food Policy 2010; 35: 20-31.

12 Ghimire SK, Awasthi B, Rana S, Rana HK, Bhattarai R, Pyakurel D. Export of medicinal and aromatic plant materials from Nepal. Botanica Orientalis: Journal of Plant Science 2016; 10: 24-32.

13 Gc A, Pun S, Devkota S, Ghimire K. Diagnostic Study of Ginger Market Access for Eastern and Western region of Nepal. Turkish Journal of Agriculture - Food Science and Technology 2019; 7.

14 Robson S. Agriculture and Economic Growth. Journal of Agricultural Economics 1970; 21: 215223.

15 Kaur R, Sidhu AS. Causal Relationship between Exports and Agricultural GDP in India. Global Business Review 2014; 15: 105-120.

16 Blecker $\mathrm{R}$ a. Long-run growth in open economies: export-led cumulative causation or a balance-ofpayments constraint? Keynesian macroeconomics and European Economic Policies 2009.

17 Toyin ME. Causality Relationship between Agricultural Exports and Economic Growth: Evidence from South Africa. Journal of Social Sciences 2016; 48: 129-136.

18 Abosedra S, Tang CF. Are exports a reliable source of economic growth in MENA countries? New evidence from the rolling Granger causality method. Empirical Economics 2019; 56: 831-841.

19 Enders W, Lee J. A unit root test using a fourier series to approximate smooth breaks. Oxford Bulletin of Economics and Statistics 2012; 74: 574-599.

20 Mackinnon JG. Numerical distribution functions for unit root and cointegration tests. Journal of Applied Econometrics 1996; 11: 601-618.

21 Vogelsang TJ. Wald-type tests for detecting breaks in the trend function of a dynamic time series. Econometric Theory 1997; 13: 818-849.

22 Narayan PK, Smyth R. Structural breaks and unit roots in Australian macroeconomic time series. Pacific Economic Review 2005; 10: 421-437. 
23 Godfrey LG, Orme CD. The Sensitivity of Some General Checks to Omitted Variables in the Linear Model. International Economic Review 1994; 35.

24 Rashid FU Sami; Bedi-uz-Zaman Ullah, Sami. Effects of exports instability on economic growth in SAARC region countries. Pakistan Journal of Commerce and Social Sciences (PJCSS) 2012; 6: 97 120.

25 Syed WA, Muhammed AU, Rana MA. Agricultural Export and Economic Growth: A Case Study of Pakistan. Public Policy and Administration Research $2015 ; \mathbf{5}$. 